Ks. Michał KIELING

(Kalisz, UAM)

\title{
FORMACJA DUCHOWNYCH W ŚWIETLE DE INSTITUTIONE CLERICORUM RABANA MAURA
}

W roku 2006 przypada 1150. rocznica śmierci wczesnośredniowiecznego teologa Rabana Maura, który należy do najwybitniejszych przedstawicieli odnowy teologicznej kultury karolińskiej. Jego życie i twórczość przypada na okres reformatorskich działań Karola Wielkiego i Ludwika Pobożnego. Szczególne znaczenie w tym kontekście miały synody w latach 816 i 819 w Akwizgranie, które odegrały ważną rolę w procesie reformy Kościoła. Jednym z najważniejszych elementów renovatio życia kościelnego była troska o odpowiednie wykształcenie i formację duchownych. Dzieło De institutione clericorum libri tres Rabana Maura jest swego rodzaju syntezą myśli na temat życia duchownych i teologii kapłaństwa.

Raban, który otrzymał przydomek Maur urodził się w 780 r. w Moguncji. Już jako dziecko oddany został na wychowanie do klasztoru w Fuldzie, gdzie przygotowywał się do życia monastycznego. Po święceniach diakonatu w 801 r. posłany został przez opata Ratgara do słynnego opactwa św. Marcina w Tours, aby pod kierunkiem Alkuina, jednego z najwszechstronniejszych teologów tamtych czasów, pogłębiać swoją wiedzę teologiczną i poznawać artes liberales. W Tours przebywał tylko jeden rok, ale pobyt ten wywarł na nim duże piętno. To właśnie Alkuin nadał mu przydomek ,Maurus", który nosił ulubiony uczeń św. Benedykta. Po powrocie z Tours osiadł w Fuldzie, gdzie pełnił obowiązki nauczyciela szkoły klasztornej. Dnia 23 grudnia 814 r. Raban otrzymał święcenia kapłańskie.

Kolejnym ważnym etapem jego życia był rok 822 , kiedy wybrany na opata klasztoru w Fuldzie, pełnił ten urząd przez 20 lat. Pod jego rządami klasztor w Fuldzie stał się miejscem rozwoju nauki i sztuki; dzięki niemu powiększono znacząco klasztorną bibliotekę i rozwinięto skryptoria. Ówczesne wydarzenia polityczne stały się jednak przyczyną rezygnacji z urzędu opata w 842 roku. Po swoim ustąpieniu, Raban przez następnych kilka lat pozostawał w Fuldzie, gdzie tworzył swoje dzieła. Dnia 26 czerwca 847 r. Ludwik Pobożny mianował go arcybiskupem Moguncji, który to urząd pełnił do końca życia. Zmarł 4 lutego 856 r. w Winkel w pobliżu Moguncji. Za zasługi położone dla rozwoju intelektualno-duchowego otrzymał zaszczytny tytuł Praeceptor Germaniae. 
Spuścizna literacka Rabana Maura zawiera przede wszystkim komentarze do prawie wszystkich ksiąg Starego i Nowego Testamentu, co uczyniło go jednym z najbardziej znaczących egzegetów wczesnego średniowiecza. Oprócz dzieł egzegetycznych pisał dzieła o charakterze encyklopedycznym, jak $D e$ rerum naturalis, oraz dzieła poświęcone życiu duchownych, teologii moralnej, wiersze i listy ${ }^{1}$. Jego dorobek teologiczny czyni go również jednym z najbardziej wszechstronnych autorów okresu karolińskiego. Był on zresztą pod wielkim wpływem teologii Ojców Kościoła, w szczególności Hieronima, Augustyna, Grzegorza Wielkiego, Orygenesa, Izydora z Sewilli i Bedy Czcigodnego.

Jednym z najważniejszych dzieł w dorobku teologicznym Rabana Maura jest jego traktat De institutione clericorum libri tres ${ }^{2}$. Dzieło to powstało w określonym kontekście historyczno-teologicznym, którym stały się karolińskie synody reformatorskie w latach $816-819^{3}$. De institutione nie jest instrukcją, czy podręcznikiem dla duchownych, ale stanowi swego rodzaju kompendium wiedzy na temat kapłaństwa. Celem pracy wczesnośredniowiecznego mnicha było zebranie w jednej księdze tego, co zostało już wcześniej napisane na temat życia duchownych ${ }^{4}$. Traktat ten dedykuje autor arcybiskupowi Moguncji Haistulfowi (813-825). Dzieło składa się z trzech ksiąg; pierwsza poświęcona jest strukturze Kościoła i porządkowi święceń, szatom kapłańskim, sakramentom oraz ordo missae według porządku rzymskiego. W drugiej księdze autor przedstawia porządek kanonicznej liturgii godzin, wyjaśnia posty, modlitwy i śpiewy, święta Pańskie oraz omawia symbol wiary i herezje. Ostatnia trzecia księga poświęcona została dochodzeniu do wiedzy i mądrości ${ }^{5}$.

${ }^{1}$ Dzieła wszystkie zob. PL 107-111; F. Stegmüller, Repertorium biblicum medii aevi, V, Madrid 1955, nr 7019-7087; Poezja: ed. E. Dümmler, w: MGH Poetae latinae medii aevii, II 154258, lub ed. G.M. Drevés, w: Analecta hymnica medii aevii, t. 50, Leipzig 1907, 180-209; Listy: MGHEp V 379-531. Poszczególne pisma: De institutione clericorum libri tres, ed. A. Knoepfler, Monachii 1900; Martyrologium, ed. J. McCulloch, CCCM 44, 3-161; De computo, ed. W.M. Stevens, CCCM 44, 165-331

${ }^{2}$ Por. D. Zimpel, Hrabanus Maurus. De institutione clericorum libri tres, w: Freiburger Beiträge zur Mittelalterlichen Geschichte, t. 7, Frankfurt am Main 1996, 7-8; PL 107, 293-440.

${ }^{3}$ Por. Zimpel, dz. cyt., s. 3; J. Semmler, Reichsidee und kirchliche Gesetzgebung (bei Ludwig d. Frommen), ZKG 71 (1960) 37-65.

${ }^{4}$ Por. De institutione clericorum Prologus, PL 107, 295CD: „Sed non in hoc satis eis facere potui, qui me instantissime postulabant immo cogebant, ut omnia haec in unum volumen, ut haberent, quo aliquo modo inquisitionibus suis satisfacerent, et in uno codice simul scriptum reperirent, quod antea non simul, sed speciatim singuli, prout interrogabant, in foliis scripta habuerant".

5 De insitutione clericorum Prologus, PL 107, 295D-296B: „Nam de hoc tres libros edidi, quorum primus de ecclesiasticis ordinibus et de veste sacerdotali continet; item de quattuor charismatibus Ecclesiae, id est: baptismo et crismate, corpore et sanguine domini et de officio missae secundum morem Romanae Ecclesiae. Secundus autem liber continet de officio canonicarum horarum et de ieiunio, confessione ac poenitentia, de legitimis quoque ieiuniis et festivitatibus variis, de lectionibus et cantu ecclesiastico, de fide catholica et econtrario de variis haeresibus. Tertius vero 
De institutione clericorum stanowi w istocie kompilację autorów patrystycznych. Zostało jednak zredagowane według koncepcji Rabana, dlatego nie brak w nim również jego własnych przemyśleń, co czyni jego traktat interesującym i wartym uwagi. Wybór autorów i tekstów przez niego cytowanych wskazuje, jak wiele pracy karoliński egzegeta poświęcił tworzeniu swojego dzieła. Lista tekstów źródłowych jest długa, począwszy od autorów patrystycznych: Tertuliana, Cypriana, Ambrożego, Hieronima, Augustyna, Kasjana, Kasjodora, Grzegorza Wielkiego, Izydora, Bedy i Alkuina, a skończywszy na tekstach soborów, listów dekretów papieskich, Ordo Romanus, Liber Pontificalis i karolińskich synodach ${ }^{6}$. Recepcja De institutione zaznacza się w całym średniowieczu, obecna szczególnie jest w liturgii. Dzieło Rabana cytowane jest przez wielu autorów jak Pseudo-Bedę, Pseudo-Alkuina, Piotra Lombarda, Ruperta z Deutz, Dekret Gracjana, Alberta Wielkiego czy Tomasza z Akwinu ${ }^{7}$. Analizując je warto postawić pytanie: czy stanowi ono tylko kompilację innych autorów, czy też zawiera nowe akcenty i tendencje odnoszące się do formacji duchownych w epoce wczesnego średniowiecza?

\section{STRUKTURA KOŚCIOŁA I WARUNKI ORDYNACJI}

Pierwsza księga poświęcona została strukturze Kościoła, stopniom święceń oraz szczegółowemu opisowi liturgicznych szat duchownych, sprawowaniu sakramentów oraz Eucharystii ${ }^{8}$. Raban Maur na wstępie swojego dzieła podejmuje myśl eklezjologiczną i podkreśla jedność oraz powszechność Kościoła. Dla chrześcijanina Bóg jest Ojcem, Kościól zaś Matką, przez którą ochrzczony zrodzony jest do życia wiary. Przynależność do Kościoła określona jest poprzez sakrament chrztu9 ${ }^{9}$. Kolejnym interesującym aspektem dzieła wczesnośredniowiecznego autora, stanowiącym pewne novum jest potrójny porządek Kościoła: laikat, mnisi i kler; najwięcej uwagi poświęca autor klerowi wyjaśniając m.in. etymologię i znaczenie słowa clericus $^{10}$.

liber edocet, quomodo omnia, quae in divinis libris scripta sunt, investiganda atque discenda sunt necnon et ea, quae in gentilium studiis et artibus Ecclesiastico viro scrutari utilia sunt".

${ }^{6}$ Por. Zimpel, dz. cyt., s. 38-61.

7 Por. tamże, s. 113-139.

${ }^{8}$ Por. De institutione clericorum I 1-33, 283-284.

${ }^{9}$ Por. De institutione clericorum I 1, 1, PL 107, 297A: „Ecclesia ergo Dei catholica, quae per totum orbem dilatata diffunditur, Christi nomine nobilitata glorificatur. Omnis enim homo, qui rectae fidei existit particeps et sacro baptismate regenaratur, a Christo christianus vocatur, et Dei Patris atque Ecclesiae matris noscitur esse filius. Ecclesia graecum est, quod in latinum vertitur convocatio sive conventus, eo quod omnes convocat ad se. Catholica autem dicitur, id est universalis, quia in toto mundo una est Ecclesia Christi, quae et sponsa et corpus eius est".

${ }^{10}$ Por. De institutione clericorum I 2, 2, PL 107, 297B: „Sunt tamen tres ordines in Ecclesia conversantium, id est laicorum, monachorum et clericorum". 
Synod w Akwizgranie w 816 r. zalecił, aby wspólnoty kanoników i kanonistów przyjęły nowe zasady życia wspólnotowego. Raban rozgranicza między laicorum, monachorum et clericorum, nie pisze jednak nic na temat ordo canonicus $^{11}$. Niektórzy widzą w tym sformułowaniu „klerykalizację życia monastycznego" i rosnącą rolę duchowieństwa diecezjalnego w życiu Kościoła. Kler według Rabana wybrany został w sposób szczególny do sprawowania rzeczy świętych i udzielania sakramentów. Autor De institutione odwołując się do typologii biblijnej przypomina, że clericus ordo powołany jest na wzór starotestamentalnego pokolenia Lewiego, które wybrano do sprawowania służby wobec Boga, Kościół zaś porównuje do Dei tabernaculum, w którym trwa nieustannie służba Boża ${ }^{12}$.

Zastanawia, że autor zaraz po pierwszych dwóch rozdziałach, poświęconych jedności i strukturze Kościoła, podejmuje zagadnienie tonsury. Powstaje pytanie, dlaczego wysuwa on na tak eksponowane miejsce kwestię tonsury i dopiero po niej omawia inne stopnie święceń i posług w Kościele? Odpowiedź na to pytanie znajdujemy w aktach synodalnych z Akwizgranu w 816 r., gdzie również na początku pojawia się zagadnienie tonsury ${ }^{13}$. W tym wypadku mamy do czynienia z przejęciem struktury i treści akt synodalnych ${ }^{14}$.

Raban wymienia osiem stopni święceń: ostiariusz, psalmista lub lektor, egzorcysta, akolita, subdiakon, diakon, prezbiter i biskup, zaś ich omówienie rozpoczyna od stopni najwyższych ${ }^{15}$. Wiele uwagi poświęca tematyce szat kapłańskich oraz sakramentów świętych, które omawia bardzo szczegółowo. Podkreślić też należy dbałość i staranność autora o szczegóły i opis detali. Wszystko to ma służyć nienagannemu i poprawnemu sprawowaniu służby Bożej i funkcji kapłańskich.

\section{FORMACJA DUCHOWNYCH}

Wczesnośredniowieczny autor podejmuje w swoim dziele również problematykę formacji duchowieństwa, przypominając o wypełnieniu odpowiednich

11 Por. Zimpel, dz. cyt., s. 14.

12 Por. De institutione clericorum I 2, 16, PL 107, 297C: „Iste autem ordo iure praeponitur in Ecclesia, quia in sanctis deservit et sacramenta populis dispensat. Sicut enim in Veteri Testamento tribus Levi prae ceteris tribubus peculiariter a Domino electa est ad serviendum illi per diversa officia in tabernaculo, ita et clericus ordo specialiter modo electus est ad ministrandum Deo in vero Dei tabernaculo, quod est Ecclesia praesens, ut serviant ei die ac nocte in templo sancto eius [...]".

13 Por. Zimpel, dz. cyt., s. 15.

14 Por. De institutione clericorum I 3, 1-45.

15 Por. tamże I 4, 2, PL 107, 299B: „Sunt autem gradus Ecclesiastici octo, quorum nomina haec sunt: ostiarius, psalmista sive lector, exorcista, acolytus, subdiaconus, diaconus, presbyter atque episcopus. Initium quidem sacerdotii in Veteri Testamento Aaron fuit, quamquam et Melchisedech prior obtulerit sacrificium et post hunc Abraham, Isaac et Iacob. Legitur et Noe altare aedificasse et super illud Domino holocaustum obtulisse". 
kryteriów przez osoby do niej powołane; odwołuje się w tym wypadku do dekretów papieża Zozyma (417-418). Należy podkreślić ponownie kontekst synodu w Akwizgranie z 816 r., na którym podjęto szereg postanowień dotyczących odpowiedniego przygotowania kandydatów do święceń. Według ówczesnych zaleceń posługa lektora lub egzorcysty miała być pełniona przez pięć lat, a posługa akolity i subdiakona trwała cztery lata. Diakonat można było otrzymać nie wcześniej jak przed dwudziestym piątym rokiem życia. Widoczny wpływ tradycji patrystycznej jest tu typowy dla tego okresu. Jeśli urząd ten sprawowany był nienagannie, to następowała po nim ordynacja do święceń prezbiteratu. Mogło to jednak nastąpić dopiero po trzydziestym roku życia, ponieważ, jak pisze autor De institutione clericorum, sam Chrystus zaczął głosić naukę dopiero po trzydziestym roku życia ${ }^{16}$.

Podejmując zagadnienie przygotowania duchownych należy wskazać na silną zależność Rabana od autorów patrystycznych. Refleksję na ten temat zawrze on przede wszystkim w trzeciej księdze, gdzie omawia wiele zagadnień dotyczących posługi duszpasterskiej. Dlatego tak bardzo podkreśla Raban potrzebę odpowiedniego przygotowania tych, którzy mają podjąć się urzędu pasterskiego.

Duchowni powinni odznaczać się pełną wiedzą, dobrym życiem i znakomitym wykształceniem ${ }^{17}$. Formacja intelektualna zajmuje ważne miejsce w przygotowaniu do posługi, chociaż Raban zdaje się jej nie przeceniać, przestrzegając przed niebezpieczeństwem popadnięcia w pychę na skutek zbyt dużej wiedzy. Wiele uwagi poświęca on teologii moralnej w znaczeniu poznania cnót i umiejętności walki z wadami. Życie oparte na cnotach winno charakteryzować powołanego do służby Bożej. Nasz Autor podkreśla również, że w procesie formacji bardzo istotna jest znajomość Pisma Świętego (scientia sanctarum scripturarum), jak i poznanie warsztatu egzegetycznego, sposobów przenośni i mowy, znaczeń mistycznych oraz użyteczności wszystkich dyscyplin. Karoliński teolog zwraca też uwagę na życie zgodne z obyczajami, sposób wyrażania się, znajomość doktryny oraz umiejętność zapobiegania niebezpieczeństwom i zagrożeniom. Dobry pasterz powinien charakteryzować się odpowiednią formacją duchową i intelektualną ${ }^{18}$. Ten ideał wychowawczy zostaje potwierdzony obszer-

${ }^{16}$ Por. tamże I 13, 2, PL 107, 306A: „Canones et decreta Zosimi papae decernunt, ut clericus, qui ad sacrum ordinem accedat, inter lectores sive exorcistas quinque annos exsolvat. Exinde acolitus vel subdiaconus quattuor annis fiat. Ad benedictionem quoque diaconatus non minoris aetatis quam XXV annorum accedat, in quo ordine quinque annis expletis, si inculpabiliter ministraverit, ad presbyteratus honorem promoveri poterit, non tamen ante tricesimum annum aetatis, licet valde dignus sit, quia et Dominus noster non ante tricesimum annum praedicare exorsus est".

17 Por. tamże III 1, 2, PL 107, 377B: „Institutio ergo ecclesiastica qualiter ad divinum officium instrui oporteat sanctissimum ordinem clericorum, multimoda narratione declarat, quia et scientiae plenitudinem et vitae rectitudinem et eruditionis perfectionem maxime eos habere decet, qui in quodam culmine constituti gubernnaculum regiminis in Ecclesia tenent".

18 Por. tamże III 1, 6, PL 107, 377B: „Nec enim eis aliqua eorum ignorare licet, cum quibus vel se vel subiectos instruere debent, id est scientiam sanctarum Scripturarum, puram veritatem his- 
nym cytatem z Księgi Reguły pasterskiej papieża Grzegorza Wielkiego z odwołaniem się do sformułowania „,ars est artium regimen animarum”19.

Podstawowym źródłem formacji teologicznej jest Pismo Święte, które jest punktem wyjścia wszelkiej mądrości i miarą wszystkich nauk. Jest ono fundamentem roztropnej wiedzy z uwagi na niezmienną wieczność, mądrość i natchnienie $^{20}$. W porównaniu $\mathrm{z}$ innymi księgami, które odkrywają mądrość, Pismo Święte jest nauczycielką i światłością wszelkiej prawdy i mądrości. Jest ono drogą poznania prawdy i mądrości, ponieważ jego lektura uzdrawia i prowadzi do poznania doskonałej prawdy i mądrości ${ }^{21}$. Wyjaśniając sposoby czytania ksiąg natchnionych autor wskazuje na wiedzę i egzegetyczne przygotowanie, które jest nieodzowne w rozumieniu ich treści. Potwierdzeniem tego jest sparafrazowany cytat z De doctrina christiana Augustyna, wyjaśniający rolę wiedzy w procesie poznawania Pisma Świętego 22 .

Zagadnienie metody czytania Pisma Świętego i trudności w jego interpretacji są elementem formacji teologicznej, której celem jest poszukiwanie sensu głębszego i studiowania Bibliii ${ }^{23}$. Autor omawia również Księgi Starego Testamentu, strukturę Pisma Świętego oraz jego powstanie ${ }^{24}$. Raban posługuje się terminami artes, doctrina, sapientia, scientia wymieniając nauki zarówno pożyteczne jak i szkodliwe.

W procesie formacji teologicznej i kształcenia intelektualnego ważną rolę spełniał system wykształcenia w artes liberales: gramatyka i jej rodzaje, retoryka, dialektyka, matematyka, arytmetyka, geometria, muzyka i astronomia ${ }^{25}$. Pełnią one użyteczną rolę w zgłębianiu treści doktryny chrześcijańskiej i poznania

toriarum, modos tropicarum locutionum, significationem rerum mysticarum, utilitatem omnium disciplinarum, honestatem vitae in probitate morum, elegantiam in prolatione sermonum, diecretionem in exibitione dogmatum, differentiam medicaminum contra varietatem aegritudinum".

${ }^{19}$ Por. tamże, III, 1, 19-69.

${ }^{20}$ Por. tamże III 2, 1, PL 107, 379B: „Fundamentum autem, status et perfectio prudentiae, scientia est sanctarum scripturarum, quae ab illa incommutabili aeternaque sapientia profluens [...]".

21 Por. tamże III 2, 12, PL 107, 379C: „Nec enim illa, quae in libris prudentium huius saeculi vera et sapientia reperiuntur, alii quam veritati et sapientiae tribuenda sunt, quia non ab illis primum statuta sunt, in quorum dictis haec leguntur, sed ab aeterno manentia magis investigata sunt, quantum ipsa doctrix et inluminatrix omnium veritas et sapientia eis investigare posse concedit. Ac ideo ad unum terminum cuncta referenda sunt, et quae in libris gentilium utilia et quae in Scripturis sacris salubria inveniuntur, ut ad cognitionem perfectam veritatis et sapientiae perveniamus, qua cernitur et tenetur summum bonum”.

${ }^{22}$ Por tamze III 6, 1 PL 107, 383A: „Sed nos his ita praelibatis, ad tertium illum gradum, id est scientiam, considerationem referamus. De quo disserere quod Dominus suggesserit atque tractare instituimus" (por. Augustinus, De doctrina christiana II 8).

${ }^{23}$ Por. De institutione clericorum III 26, 38, PL 107, 405 A: „Sed hoc modo instructus divinarum scripturarum studiosus, cum ad eas scrutandas accedere ceperit, illud apostolicum cogitare non cesset: Scientia inflat, caritas aedificat".

${ }^{24}$ Por. tamże II 53-54.

25 Por. tamże III 18-25. 
Pisma Świętego ${ }^{26}$. Studiowanie świeckich nauk jest też pożyteczne dla teologów, którzy mogą wiele z nich skorzystać w ramach przygotowywania homilii.

Dialektykę określa Raban jako „disciplina disciplinarum”, bowiem ona „docet docere, haec docet discere"27. Znajomość dialektyki potrzebna jest do rozróżniania dobra od zła, pełni także pomocną rolę w walce z herezjami. Dlatego zachęca duchownych do zgłębiania tej wiedzy, bo posiada ona w tym wypadku szczególne znaczenie ${ }^{28}$. Jeśli chodzi o wtajemniczenie w artes liberales, to wskazuje się na Alkuina jako najważniejsze źródło dla dzieła Rabana ${ }^{29}$ oraz na pisma innych autorów jak: Institutiones Kasjodora, De doctrina christiana Augustyna i Etymologiae Izydora z Sewilli ${ }^{30}$. Raban podkreśla również przydatność pism filozoficznych ${ }^{31}$ i zauważa, że celem uprawiania nauk świeckich jest ich użyteczność dla doktryny teologicznej ${ }^{32}$. W sformułowaniach karolińskiego teologa można zauważyć pozytywne odniesienie do nauk świeckich, które towarzyszą formacji duchownych i przyczyniają się do podniesienia ich poziomu intelektualnego.

Formacja ta nie oznacza jednak tylko wymiaru naukowego, ale zakłada jednoczesny rozwój duchowy. Na pierwsze miejsce wysuwa się tu nauka o cnotach kardynalnych (prudentia, iustitia, fortitudo, temperantia) i potrzeba ćwiczenia się w cnotach oraz poszukiwaniu bogactwa duchowego ${ }^{33}$. Karoliński

${ }^{26}$ Por. tamże III 15, 25, PL 107, 392B: „Nunc de his, quae in gentilibus doctrinis exercentur, et quae liberales dicuntur artes qui conferant utilitatis, si perscrutentur his, qui canonicas Scripturas legunt, quantum valeo explicabo".

27 Por. tamże III 20, 2, PL 107, 397CD: „Haec ergo disciplina disciplinarum est, haec docet docere, haec docet discere, in hac se ipsa ratio demonstrat atque aperit, quae sit, quid velit, quid valeat. Scit scire sola et scientes facere non solum vult, sed etiam potest. In hac ratiocinantes cognoscimus, quid sumus et unde sumus; per hanc intelligimus, quid sit faciens bonum et quid factum bonum, quid creator et quid creatura; per hanc investigamus veritatem et deprehendimus falsitatem".

${ }^{28}$ Por. tamże III 20, 14, PL 107, 397D: „Quapropter oportet clericos hanc artem nobilissimam scire, eiusque iura in assiduis meditationibus habere, ut subtilem haereticorum versutiam hac possint dignoscere, eorumque dicta venefica veris syllogismorum conculsionibus confutare".

29 Por. Zimpel, dz. cyt., s. 86.

${ }^{30}$ Por. tamże, aparat krytyczny, s. 468-484.

31 Por. tamże III 26, 2, PL 107, 404A: „Ecce de septem liberalibus artibus philosophorum, ad quam utilitatem discendae sint catholicis, satis, ut reor, superius diximus; illud adhuc adicimus, quod philosophi ipsi qui vocantur, si qua forte vera fidei nostrae accomodata in disputationibus suis seu scriptis dixerunt, maxime Platonici, non solum formidanda non sunt, sed ab eis etiam tamquam iniustis possessoribus in usum nostrum vindicanda".

32 Por. tamże III 18, 43: „Haec si secundum litteram intellegimus nonne ridicula sunt? Itaque et nos hoc fecere solemus hocque facere debemus, quando poetas gentiles legimus, quando in manus nostras libri veniunt sapientiae saecularis, si quid in eis utile reperimus, ad nostrum dogma convertimus, si quid vero superfluum de idolis, de amore, de cura saecularium rerum, haec radimus, his calvitium inducamus, haec in unguium more ferro acutissimo descemus".

${ }^{33}$ Por. tamże III 27, 1, PL 107, 405B,: „Interea quippe dum intenta meditatione scientiam spiritalem optat adipisci, necesse est, ut iugi exercitio virtutum sibi quaerat opulentiam, ne dum in uno dives esse cupit, et alterius opes quaerere negligit, verae opulentiae fructus perdat; ac non 
teolog zestawia ze sobą mądrość i cnotę podkreślając ich użyteczność, ponieważ one posiadają perspektywę eschatologiczną i ukierunkowują życie człowieka ku wieczności. Życie oparte na cnotach oznacza wypełnianie Bożych przykazań i realizację planu własnego zbawienia ${ }^{34}$. Cnoty kardynalne pełnią rolę drogowskazów prowadzących przez życie do wieczności. Autor De institutione akcentuje ich przydatność i potrzebę wzrastania w nich nie tylko w odniesieniu do duchownych, ale również do wszystkich wierzących ${ }^{35}$. Interesujące jest zestawienie wiedzy z cnotami, które ukazuje ich rolę w procesie doskonalenia mądrości i życia chrześcijańskiego ${ }^{36}$. Raban zestawia również cnoty i wady, opisuje zagrożenia życia duchowego i analizuje je $\mathrm{j}^{37}$.

Wiele miejsca poświęca też autor De institutione clericorum przepowiadaniu Słowa Bożego. Ostatnich dziewięć rozdziałów jego dzieła to refleksja nad sztuką przepowiadania, w których praktycznie zestawia dorobek Ojców Kościoła: z Augustyna cytuje fragmenty De doctrina christiana, a z Grzegorza Wielkiego wybrane teksty z Księgi Reguty pasterskiej ${ }^{38}$. Podkreśla, jak wielka jest odpowiedzialność tego, który podejmuje się nauczania i interpretacji Pisma Świętego. Określa go słowami; tractator (człowiek zajmujący się nauką), doctor (nauczyciel), defensor rectae fidei (obrońca prawdziwej wiary) i debellator erroris (zwycięzca błędów) ${ }^{39}$. Kaznodzieja powinien odznaczą się umiłowaniem

solum ipsi eveniat, quod quaesitarium rerum utilitatem non habeat; immo poenas iniustus possessor pro eis Domino solvat".

${ }^{34}$ Por. tamże III 27, 18, PL 107, 405CD: „Oportet quidem eum, qui sapientiae studet, virtuti studere, ut id quod sapienter intellegit in mente, utiliter exerceat in opere; et quodcumque boni verbis aliis facere praecipit, suis operibus feciendum esse prius doceat, ut faciens et docens mandata Dei, maior vocetur in regno caelorum: non minimus autem, si docuerit ore et solverit actione unum de mandatis Dei minimis".

35 Por. tamże III 27, 29 PL 107, 406A: „Debet autem unusquisque catholicus universis virtutibus aequaliter operam dare, ut et intus et foris nobiliter ornatus, aeterni regis convivio dignus existat, et quadriga spiritali vectus ad aeternam patriam conscendat".

${ }^{36}$ Por. tamże III 27, 39, PL 107, 406B: „His autem speciebus virtutum perfecte adornatus, et sapientiae lumine illustratus homo Dei rite ac congrue servitium eius potest agere atque oratoris officium digne potest in Ecclesia implere: quem antiqua definitio adfirmat, virum bonum et dicendi peritum esse debere".

${ }^{37}$ Por. tamże III 38, 9, PL 107, 416AB: „Sunt et e contrario in vitiis quaedam virulentia germina, de quibus omnis illa multitudo pestifera nequitiarum generatur, et sicut in virtutibus aliae ex aliis quasi procedunt ex genetricibus proles speciosae, sic et in istis quaedam quasi nequissimae soboles ex spurcissimis matribus prodeunt. Sed quia cum virtutibus vitiorum diuturna sunt bella, utriusquae militiae qui sunt duces, quique eorum sunt comites, specialiter quantum possumus exponamus; ita tamen, ut, quae virtus cum quo vitio propriae pugnam gerat, pariter ostendamus. Nec enim aliter possumus ignita vitiorum iacula devitare, nisi sciamus opportuna virtutum tegmina illis opponere, ut ex ipsis defensi protervum illum exercitum simul cum eius ducibus Christo super nos regnante possimus superare".

38 Por. Zimpel, dz. cyt., aparat krytyczny: s. 489-520.

39 Por. De institutione clericorum III 28, 2, PL 107, 406C: „Debet igitur divinarum Scripturarum tractator et doctor, defensor rectae fidei ac debellator erroris, et bona docere et mala dedocere 
słowa i głosić je w sposób zrozumiały. Zasada, na której powinno opierać się jego przepowiadanie, jest następująca: pouczać, pocieszać, ganić (ut doceat, ut delectet, ut flectat ${ }^{40}$. Potrzeba, zatem, aby eloquentia ecclesiastica nie tylko zachęcała do czynów i nauczała, lecz aby wskazywała drogę życia chrześcijańskiego $^{41}$. Raban pisze o trzech rodzajach nauczania: inaczej należy odnosić się do spraw o małym znaczeniu, inaczej o średnim, natomiast w sprawach o wielkim znaczeniu należy mówić dobitnie ${ }^{42}$. Analizuje też poszczególne grupy słuchaczy i zachęca, aby kaznodzieja uwzględniał poziom swoich słuchaczy i dostosowywał do nich swoje przepowiadanie ${ }^{43}$, cytując w tym miejscu obszerny fragment Księgi Reguty pasterskiej Grzegorza Wielkiego.

\section{DUCHOWOŚĆ EUCHARYSTYCZNA}

Eucharystii oraz oficjum mszalnemu zostały poświęcone trzy rozdziały pierwszej księgi De institutione clericorum. Karolińskiego teologa cechuje dbałość o zachowanie prawa liturgicznego i poprawność sprawowania sakramentów oraz ujednolicanie praktyk liturgicznych. Zapewne wyniesiona z doświadczeń życia monastycznego w Tours czy Fuldzie dbałość o liturgię odzwierciedla się w jego traktacie, który może służyć jako źródło wiedzy o liturgii i sakramentach owego czasu. W swym traktacie autor w kilku miejscach podejmuje refleksję nad sprawowaniem tego sakramentu ${ }^{44}$, zaś jego rozdział $31 \mathrm{w}$ całości

atque in hoc opere sermone conciliare aversos, remissos erigere, nescientibus quid agere, quid expectare debeant intimare".

${ }^{40}$ Por. tamże III 31, 3, PL 107, 408D: „Est autem optimus modus dicendi, quo fit, ut qui audit, verum audiat, et quod audit intellegat; bonorumque ingeniorum insignis est indoles, in verbis verum amare, non verba [...]. Dixit ergo quidam eloquens, et verum dixit, ita dicere debere eloquentem, "ut doceat, ut delectet, ut flectat». Deinde addidit: «Docere necessitatis est, delectare suavitatis et flectere victoriae»" (por. Augustinus, De doctrina christiana IV 12).

${ }^{41}$ Por. De institutione clericorum III 31, 23, PL 107, 409B: „Oportet igitur eloquentem Ecclesiasticum, quando suadet aliquid, quod agendum est, non solum docere, ut instruat, et delectare, ut teneat, verum etiam flectere, ut vincat" (por. Augustinus, De doctrina christiana IV 13).

${ }^{42}$ Por. tamże III 32, 3, PL 107, 409BC: „Ad haec enim tria, id est ut doceat, ut delectet, ut flectet, etiam illa tria videtur pertinere voluisse idem, ipse Romani auctor eloquii, cum totidem dixit: Is erit igitur eloquens, qui poterit parva submisse, modica temperate, magna granditer dicere; tamquam si adderet illa etiam tria et sic explicaret unam eandemque sententiam dicens: Is erit igitur eloquens, qui, ut doceat, poterit parva submisse, ut delectet modica temperate, ut flectat magna granditer dicere".

43 Por. tamże III 37, 2, PL 107, 413C: „Hoc quoque nosse convenit unumquemque catholicum doctorem, quomodo sibi conciliet sui sermonis auditorem, ut dum sciat per supradictam rationem modos locutionum et species, bene dispensando fructus inveniat suae praedicationis et laudes. Cum enim orationis exhibet perfectionem, necesse est, ut perpendat auditorum qualitatem [...]" (por. Gregorius, Regula pastoralis III Prologus).

${ }^{44}$ Por. tamże I 5, 33, PL 107, 301C: „Dispensat ergo mysteria caelestia fidelibus, baptismum tradit, corpus et sanquinem Christi distribuit et verbum praedicat”; I 6, 19, PL 107, 302B: „Ideo 
poświęcony został tej tematyce. Na uwagę zasługuje fakt, że Raban Maur nie posłużył się w tym wypadku kompilacją cudzych wypowiedzi, lecz wprowadził własną refleksję ${ }^{45}$. Wczesnośredniowieczny autor stawia pytania: dlaczego Pan zostawił siebie pod postaciami chleba i wina wybierając owoce tej ziemi? W odpowiedzi zaznacza, że przez rzeczywistość widzialną chciał Pan wskazać na niewidzialne misteria ${ }^{46}$. Używając argumentacji biblijnej omawia on sakrament Eucharystii koncentrując się na interpretacji wybranych miejsc. Akcentuje przy tym myśl eschatologiczną, że przez udział w tym sakramencie osiągamy życie wieczne, ale podkreśla również wpływ Eucharystii na życie doczesne człowieka wskazując na skuteczność tego sakramentu ${ }^{47}$.

Karoliński autor poświęca też wiele uwagi samej Mszy św. oraz podkreśla jej ofiarniczy charakter i rolę kapłana jako pośrednika między Bogiem a ludź$\mathrm{mi}^{48}$. Troska o zachowywanie właściwego oficjum Mszy św. zaakcentowana jest bardzo wyraźnie. Autor omawia po kolei jej części: introitus, oratio, responsorium, alleluia, evangelium, offertorium, sanctus, consecratio corporis et sanguinis Domini, agnus Dei, communio, benedictio ${ }^{49}$. Na uwagę zasługuje tu końcowe sformułowanie Rabana, który akcentuje tradycję apostolską i rzymską Mszy św., co było zresztą zgodne z zaleceniem upowszechniania tradycji rzymskiej w liturgii ${ }^{50}$.

autem presbiteri sacerdotes vocantur, quia sacrum dant, sicut episcopi, id est in confectione divini corporis et sanguinis, et in baptismate, et in officio praedicandi”; II 36, 15, PL 107,347D: „Eodem etiam die, sicut supra ostendimus, poenitentes reconciliantur, quia scilicet ipsa die, qua sacramenta corporis et sanguinis sui Dominus primum confecit ac discipulis suis percipienda tradidit, oportebat ad haec resumenda poenitentiales restaurentur eo videlicet tempore, quo sanguis Christi in remissionem omnium fusus est peccatorum".

45 Por. tamże I 31, 5, PL 107, 316C: „Ac primum nobis quaerendum est, cur Dominus corporis et sanguinis sui mysteria in his rebus sanciri voluisset, quae comedi et consumi possunt, et non potius in his, quae maiore honore servata diutius integra haberi potuissent; deinde - cur cibo et potu idem sacramentum fieri voluisset - cur ex terrenis fructibus, quibus communi usu terrestres uterentur, et non magis ex alia aliqua re illud traderet [...]".

46 Por. tamże I 31, 17, PL 107, 316D: „Maluit enim Dominus corporis et sanguinis sui sacramenta fidelium ore percipi et in pastum eorum redigi, ut per visibile opus invisibilis ostenderetur effectus".

${ }^{47}$ Por. tamże I 31, 63, PL 107, 317D-318A: „Sacramentum enim ore percipitur, virtute sacramenti interior homo satiatur. Sacramentum in alimentum corporis redigitur, virtute autem sacramenti aeterna vita adipiscitur. In sacramento fideles quique communicantes pactum societatis et pacis ineunt: in virtute autem sacramenti omnia membra capiti suo coniuncta et coadunata in aeterna claritate gaudebunt. Sicut ergo in nos id convertimur, dum oboedienter et pie vivimus".

48 Por. tamze I 32, 19, PL 107, 322A: „Missa autem est legatio inter Deum et homines, cuius legationis officio fungitur sacerdos, cum populi vota per preces et supplicationes ad Deum offert. Et bene hoc tempore sacrificii fit, quando illius passionis memoria celebratur".

${ }^{49}$ Por. tamże I 33, 1-75.

${ }^{50}$ Por. tamze I 33, 75, PL 107, 324C: „Istum ergo ordinem ab apostolis et ab apostolicis viris traditum Romana tenet Ecclesia et per totum pene Occidentem omnes Ecclesiae eandem traditionem servant". 
Dzieło Rabana Maura De institutione clericorum libri tres stanowi, jak widać, interesujące źródło poznania teologii kapłaństwa w epoce wczesnego średniowiecza i jest swego rodzaju kompendium wiedzy na ten temat. Traktat karolińskiego teologa jest w zasadzie kompilacją dzieł Ojców Kościoła, pisarzy i dokumentów kościelnych, co nie umniejsza jego wartości i roli, jaką odegrał w epoce średniowiecza. Nie znajdujemy w nim nowych czy oryginalnych treści, na uwagę jednak zasługują pewne aspekty i tendencje w odniesieniu do reformy Kościoła, która oparta została na ustawodawstwie kościelnym Ludwika Pobożnego podczas synodów w latach 816 i 819 . Celem tej reformy było zarówno ujednolicenie życia duchownych, organizacja życia mnichów oraz kleru, jak i odnowa liturgii. Miejsce szczególne w tym kontekście zajmuje formacja duchownych w wymiarze wewnętrznym i intelektualnym. Troska o odpowiednie i wszechstronne wykształcenie duchowieństwa stała się w istocie punktem wyjścia do odnowy całego życia kościelnego w epoce karolińskiej. $\mathrm{Na}$ pierwszy plan wysuwa się właściwe przygotowanie do podjęcia posługi duszpasterskiej oparte na studiowaniu Pisma Świętego, solidnym przygotowaniu egzegetycznym do przepowiadania słowa Bożego, znajomości teologii, zgłębianiu artes liberales, trosce o staranne sprawowanie sakramentów, poprawności liturgicznej oraz kształtowaniu duchowości eucharystycznej. Oprócz aspektów intelektualnych warto też nadmienić zalecenia odnoszące się do życia duchownych, które powinno być oparte na cnotach oraz nienagannie zdążać do świętości i być wyrazem służby Bożej.

\section{DIE FORMATION DES GEISTLICHEN IM LICHTE DE INSTITUTIONE CLERICORUM VON HRABANUS MAURUS}

(Zusammenfassung)

Geborene um 780 in Mainz Hrabanus Maurus gehört zu den zentralen Gestalten der karolingischen Theologie und Kultur. Sein schriftstellerisches Werk ist von auerordentlichen Umfang, wobei die Bibelkommentare ein Schwerpunkt bilden. Sein Werk De institutione clericorum libri tres steht in engem Zusammenhang mit den Synoden im 816 und 819 und vermittelt die geistige Gesetzgebung Ludwigs des Frommen. Der Verfasser dieses Aufsatzes beschäftigt sich mit der geistigen und intellektuellen Formation der Mönche und Kleriker im Lichte dieses Werkes. De Institutio clericorum ist im Grunde eine Kompitation, aber in diesem Werk kann man auch interessante Aspekte der theologischen Erneuerung zu finden; sie leistet 
einen Beitrag zur Durchsetzung für die damalige Zeit neuen Bestimmungen. So zum Beispiel die Sorge um das Studium der Heiligen Schrift, die Hebung des artes liberales und der weltlicher Wissenschaften. Hrabanus Maurus betont in seinem Werk die Rolle der Sakramente, darunter Eucharistie, Liturgie und den Tugenden im geistigen Leben. Sein Werk spiegelt die frühmittelalterliche Formation und Ausbildung des Geistlichen im Kontext des karolingischen Erneuerung auf. 